\title{
Electrical conductivity of molten fluoride-oxide melts with high addition of aluminium fluoride
}

\author{
Emília Kubiňáková, Ján Híveš, Vladimír Danielik \\ Institute of Inorganic Chemistry, Technology and Materials, \\ Faculty of Chemical and Food Technology STU in Bratislava, \\ Radlinského 9, 81237 Bratislava, Slovak Republic \\ emilia.kubinakova@stuba.sk
}

\begin{abstract}
Electrical conductivity of $\mathrm{NaF}_{-} \mathrm{AlF}_{3}$ melts with an addition of 2 wt $\% \mathrm{Al}_{2} \mathrm{O}_{3}$ and/or 5 wt $\% \mathrm{CaF}_{2}$ was measured using a pyrolytic boron nitride tube-type cell with a constant distance of electrodes. The molar cryolite ratios $\mathrm{MR}=\mathrm{n}(\mathrm{NaF}) / \mathrm{n}\left(\mathrm{AlF}_{3}\right)$ were 1.8 and 1.6 , and the temperature was varied from $865^{\circ} \mathrm{C}$ to $1005^{\circ} \mathrm{C}$. Ac-techniques with a sine wave signal with small amplitude in the high frequency range were applied. Electrolyte resistance was obtained from nonlinear regression analysis according to equivalent circuit. Experimental data were used to describe the dependence of the electrical conductivity in fluoride melts with lower temperature on the amount of various additions and temperature.
\end{abstract}

Keywords: electrical conductivity, cryolite based melts, boron nitride, tube-type cell

\section{Introduction}

Electrolytes used in aluminium production have high melting temperatures of about $960{ }^{\circ} \mathrm{C}$. In this electrolytic process, alumina is dissolved in fluoride melts based on sodium cryolite. The electrolyte is modified by an addition of aluminium fluoride, calcium fluoride and also by small amounts of other additives, such as lithium fluoride or magnesium fluoride (Kvande and Drabløs, 2014). Interest in electrolytes with lower working temperature is caused by the corrosion rate of the electrolyser construction materials being substantially lower. Moreover, inert, low-consumption materials can be used for anodes and cathodes in the electrolysis cell (Thonstad et al., 2001; Galasiu et al., 2007).

In terms of lower temperature, systems with higher addition of aluminium fluoride seem very interesting. An increased amount of $\mathrm{AlF}_{3}$ significantly decreases the working temperature but also changes other physico-chemical properties of the electrolyte. One of the disadvantages of these melts is their lower electrical conductivity in comparison with that of the currently used type of melts (Solheim and Sterten, 1997; Híveš et al., 1993). Determination of electrical conductivity in case of fluoride-oxide mixtures is rather complicated. Selection of a suitable material for the conductance cell is very important as it cannot be attacked by the melt and it should have dimensional stability at temperatures of about $1000{ }^{\circ} \mathrm{C}$. Pyrolytic boron nitride (BN) is currently one of the most suitable construction materials for measuring cells. Calibration techniques also play an important role. The main experimental techniques employing pyrolytic BN are so called CVCG (Continuously Varying Cell Constant) moving electrode technique (Wang et al., 1993; Kan et al., 2007; Bakin et al., 2010) and tube-type cell with fixed position of electrodes (Híveš et al., 1996; Híveš and Thonstad, 2004; Uher et al., 2009).

Electrical conductivity of low-temperature cryolite based melts has been investigated in recent years (Redkin and Tkacheva, 2010; Cassayre et al., 2010). This property of an electrolyte is of particular importance because it affects the ohmic voltage drop in the electrolytic cell. In the industrial production of aluminium, it is essential to apply melts with high electrical conductivity to increase current efficiency and reduce energy consumption. Moreover, research on electrical conductivity can help to study the structure of melts.

\section{Experimental}

\section{Chemicals}

Aluminium fluoride was purified by sublimation in a platinum crucible at the temperature of $1250^{\circ} \mathrm{C}$. Alumina, sodium fluoride, calcium fluoride and sodium chloride, all of analytical grade, were dried for $3-5$ hours at $400-500{ }^{\circ} \mathrm{C}$ before use.

\section{Apparatus and measuring techniques}

The cell for electrical conductivity measurement is schematically shown in Fig. 1; it consists of a pyrolytic boron nitride tube (CERAMISIS, United Kingdom) of the inner diameter of $5 \mathrm{~mm}$, outer diameter of $6 \mathrm{~mm}$ and the length of $100 \mathrm{~mm}$. One electrode is comprised of a tungsten rod with its 
diameter gradually reduced from $3 \mathrm{~mm}$ to $2 \mathrm{~mm}$, thus ensuring the fixed position of the electrode in the BN tube. A graphite crucible served as the other electrode. The crucible containing $11 \mathrm{~g}$ of the salt mixture was placed into a vertical laboratory furnace with controlled argon atmosphere (99,996 \%) and a cooling jacket. Temperature was monitored using a Pt-Pt10Rh thermocouple which controlled the temperature within $\pm 0.3^{\circ} \mathrm{C}$ during the whole measurement. After melting and homogenization of the melt at the required temperature, the boron nitride tube and the end of the tungsten electrode were immersed into the electrolyte.

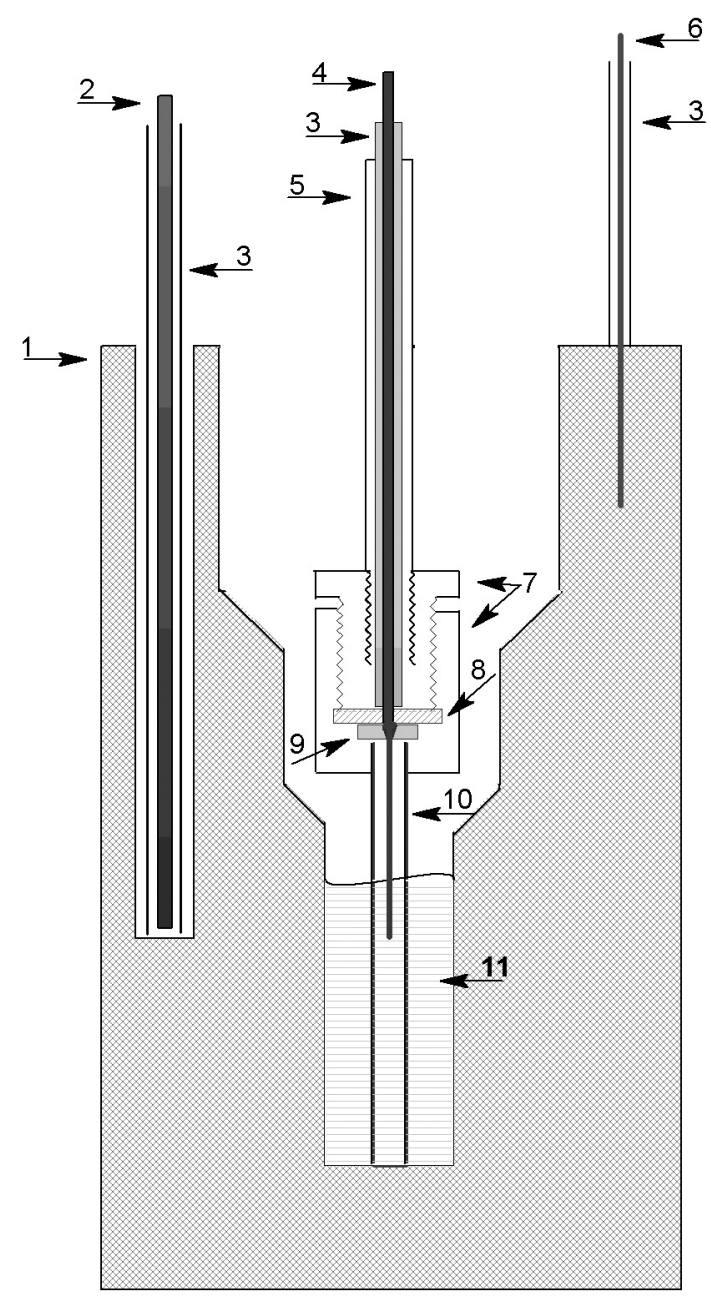

Fig. 1. Cell for electrical conductivity measurement: (1) graphite crucible, (2) thermocouple, (3) alumina tube, (4) tungsten electrode, (5) stainless steel tube, (6) steel contact rod, (7) cell body of hot pressed $\mathrm{BN}$, (8) insulating ring of hot pressed $\mathrm{BN}$, (9) terminative stainless steel ring, defining the diameter of the tungsten rod, (10) pyrolytic BN tube, (11) molten electrolyte.

$A c$-techniques are used with a sine wave signal with small amplitude $5-10 \mathrm{mV}$ in the high frequency range varying from $100 \mathrm{~Hz}$ to $100 \mathrm{kHz}$. A Solar- tron Impedance/Gain Phase Analyzer 1260 and a Solartron ECHI 1287 were used to measure cell impedance. Electrolyte resistance was obtained from nonlinear regression analysis of the measured impedance diagram according to the proposed equivalent circuit. Electrical conductivities were calculated from the values of the electrolyte resistance and from the defined conductivity cell constant (calibrated on sodium chloride).

\section{Results and discussion}

Systems $\mathrm{NaF}-\mathrm{AlF}_{3}, \mathrm{NaF}-\mathrm{AlF}_{3}-\mathrm{Al}_{2} \mathrm{O}_{3}$, $\mathrm{NaF}-\mathrm{AlF}_{3}-\mathrm{CaF}_{2}$ and $\mathrm{NaF}-\mathrm{AlF}_{3}-\mathrm{Al}_{2} \mathrm{O}_{3}-\mathrm{CaF}_{2}$ with the molar ratio $M R=1.8$

The basic melt was composed of $64 \mathrm{~mol} \%$ of $\mathrm{NaF}$ and $36 \mathrm{~mol} \%$ of $\mathrm{AlF}_{3}$, corresponding to the molar ratio of 1.8. Amounts of 2 wt \% of $\mathrm{Al}_{2} \mathrm{O}_{3}$ and/or $5 \mathrm{wt} \%$ of $\mathrm{CaF}_{2}$ were added into the multi-component systems. The operating temperature varied within the range of $910{ }^{\circ} \mathrm{C}$ to $1004{ }^{\circ} \mathrm{C}$, while the lowest temperature reached the value about $10^{\circ} \mathrm{C}$ above the temperature of primary crystallization.

Fig. 2 shows the experimental conductivity data as a function of temperature for melts with less pronounced excess of $\mathrm{AlF}_{3}$. Each point represents an average value from at least three different experiments. Uncertainly of the experiments was ca $2 \%$. Electrical conductivity of all cryolite melts increased with the increasing bath temperature. On the other hand, an addition of alumina caused significant decrease in the electrical conductivity when compared with that of basic melt. The same trend of electrical conductivity decrease was expected also with the addition of calcium fluoride. Negative influence of calcium fluoride was suppressed in these melts with lower molar ratio, $\mathrm{MR}=1.8$. The combination of alumina and calcium fluoride led to a more significant decrease in the electrical conductivity than in the $\mathrm{NaF}-\mathrm{AlF}_{3}-\mathrm{Al}_{2} \mathrm{O}_{3}$ melt although the influence of calcium fluoride seemed to be negligible in the $\mathrm{NaF}-\mathrm{AlF}_{3}-\mathrm{CaF}_{2}$ system.

Systems $\mathrm{NaF}-\mathrm{AlF}_{3}, \mathrm{NaF}-\mathrm{AlF}_{3}-\mathrm{Al}_{2} \mathrm{O}_{3}$, $\mathrm{NaF}-\mathrm{AlF}_{3}-\mathrm{CaF}_{2}$ and $\mathrm{NaF}-\mathrm{AlF}_{3}-\mathrm{Al}_{2} \mathrm{O}_{3}-\mathrm{CaF}_{2}$ with the molar ratio $M R=1.6$

Composition of the basic melt was $61.5 \mathrm{~mol} \%$ of $\mathrm{NaF}$ and $38.5 \mathrm{~mol} \%$ of $\mathrm{AlF}_{3}$. A slightly higher increment of aluminium fluoride corresponds to the molar ratio of 1.6. The same additions of $2 \mathrm{wt} \%$ of $\mathrm{Al}_{2} \mathrm{O}_{3}$ and/or 5 wt \% of $\mathrm{CaF}_{2}$ were used also in these baths. The operating temperature varied within the range of $867{ }^{\circ} \mathrm{C}$ to $955^{\circ} \mathrm{C}$. The lowest operating temperature of the basic melts $\left(\sim 875^{\circ} \mathrm{C}\right)$ decreased with an addition of components, same as in previous experiments. 


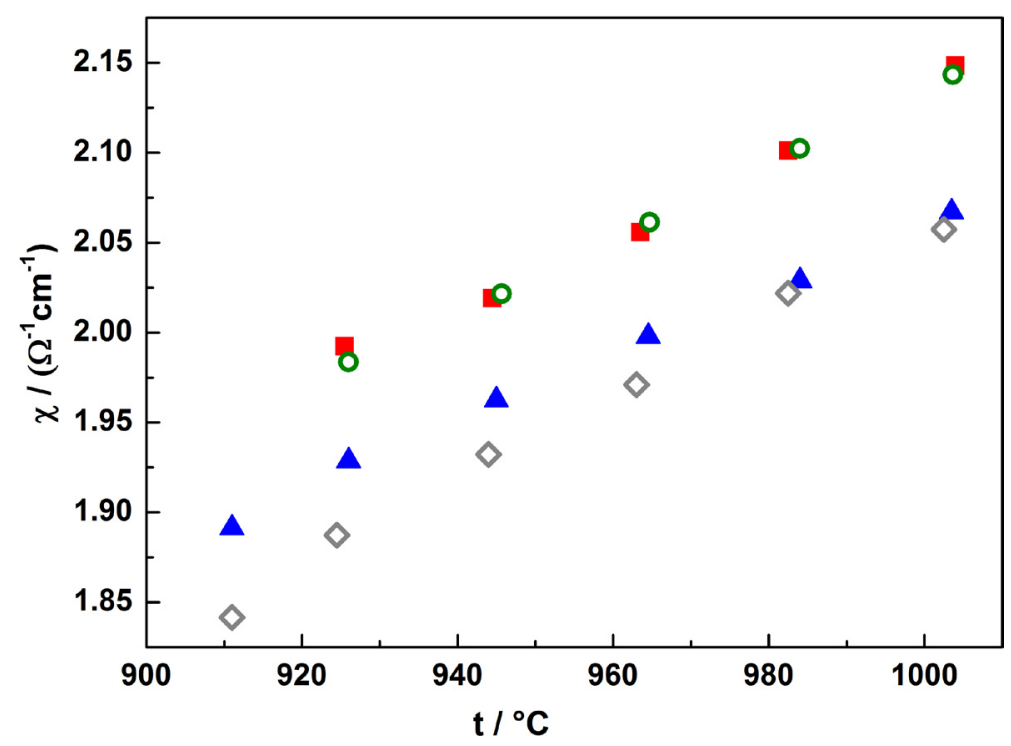

Fig. 2. Electrical conductivity of $\mathrm{NaF}-\mathrm{AlF}_{3}, \Delta \mathrm{NaF}-\mathrm{AlF}_{3}-\mathrm{Al}_{2} \mathrm{O}_{3}\left(2\right.$ wt \%) $\circ \mathrm{NaF}-\mathrm{AlF}_{3}-\mathrm{CaF}_{2}(5$ wt \%) and $\diamond \mathrm{NaF}-\mathrm{AlF}_{3}-\mathrm{Al}_{2} \mathrm{O}_{3}-\mathrm{CaF}_{2}$ systems as a function of temperature. Composition of basic melt: $64 \mathrm{~mol} \%$ of $\mathrm{NaF}$ and $36 \mathrm{~mol} \%$ of $\mathrm{AlF}_{3}(\mathrm{MR}=1.8)$.

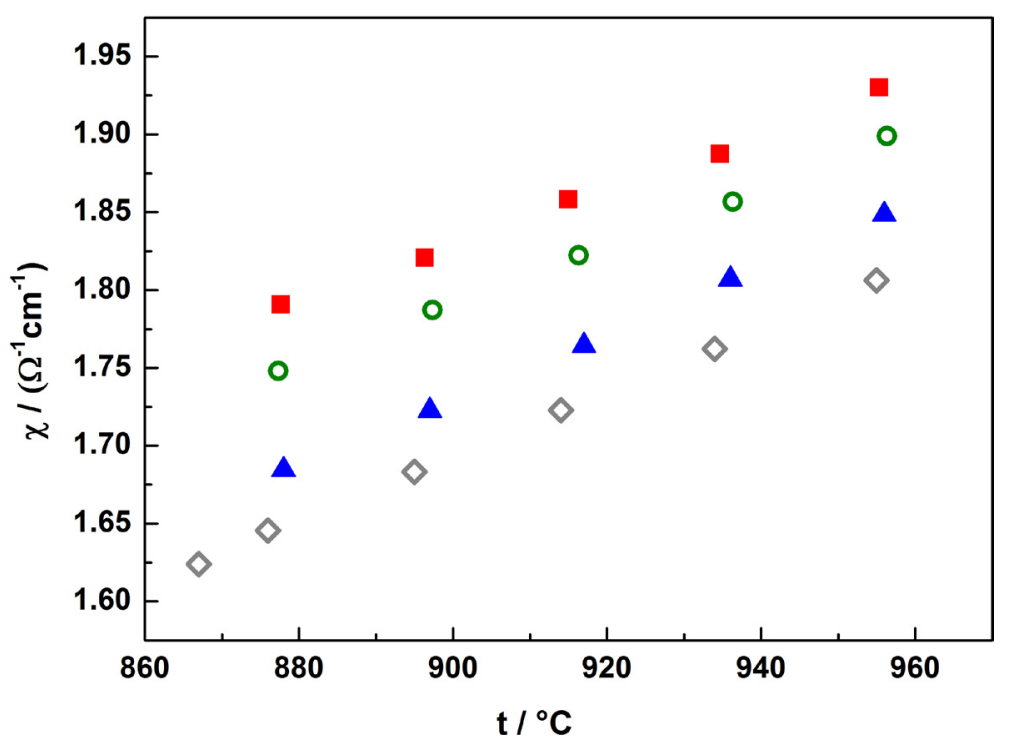

Fig. 3. Electrical conductivity of $\mathrm{NaF}_{-} \mathrm{AlF}_{3}, \boldsymbol{\mathrm { NaF }}-\mathrm{AlF}_{3}-\mathrm{Al}_{2} \mathrm{O}_{3}\left(2\right.$ wt \%) $\circ \mathrm{NaF}-\mathrm{AlF}_{3}-\mathrm{CaF}_{2}(5$ wt \%) and $\diamond \mathrm{NaF}-\mathrm{AlF}_{3}-\mathrm{Al}_{2} \mathrm{O}_{3}-\mathrm{CaF}_{2}$ systems as a function of temperature. Composition of basic melt:

$61.5 \mathrm{~mol} \%$ of $\mathrm{NaF}$ and $38.5 \mathrm{~mol} \%$ of $\mathrm{AlF}_{3}(\mathrm{MR}=1.6)$.

Influence of a higher addition of $\mathrm{AlF}_{3}$ in different cryolite melts on electrical conductivity as a function of temperature is shown in Fig. 3. Higher bath temperatures and alumina addition have the same influence on the electrical conductivity as in previous systems. A slight difference is visible in melts containing calcium fluoride, where the drop of electrical conductivity is evident at all temperatures. Electrical conductivity of a four-component system reaches markedly lower values than in the basic electrolyte with a decline of about $6-8 \%$.
A comparison of measured data in three-component systems with those obtained for the basic ones is shown in Fig. 4, while in Fig. 5, a comparison of the measured electrical conductivity of four-component systems with that of the basic melts is presented.

\section{Conclusion}

Variations of electrical conductivity in sodium cryolite melts with different molar ratio $\mathrm{MR}=\mathrm{n}(\mathrm{NaF}) /$ $/ \mathrm{n}\left(\mathrm{AlF}_{3}\right)$, with an addition of $\mathrm{Al}_{2} \mathrm{O}_{3}$ and/or $\mathrm{CaF}_{2}$ in 


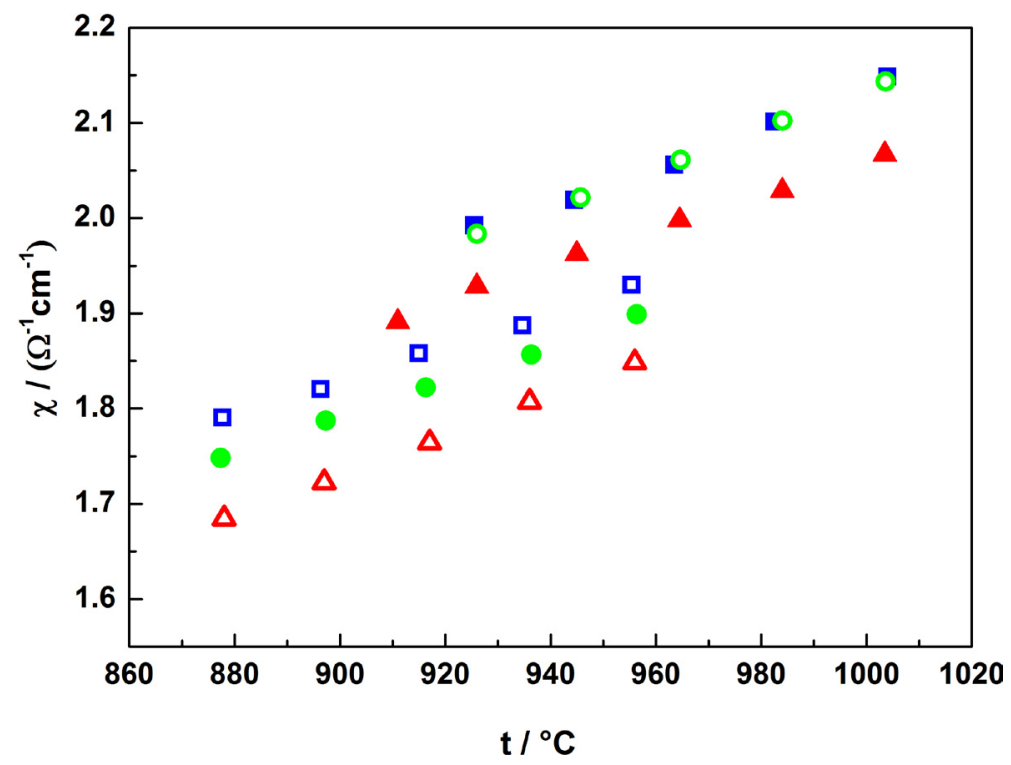

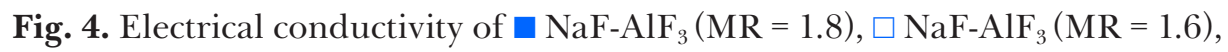

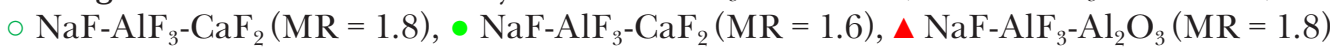
and $\Delta \mathrm{NaF}-\mathrm{AlF}_{3}-\mathrm{Al}_{2} \mathrm{O}_{3}(\mathrm{MR}=1.6)$ systems as a function of temperature.

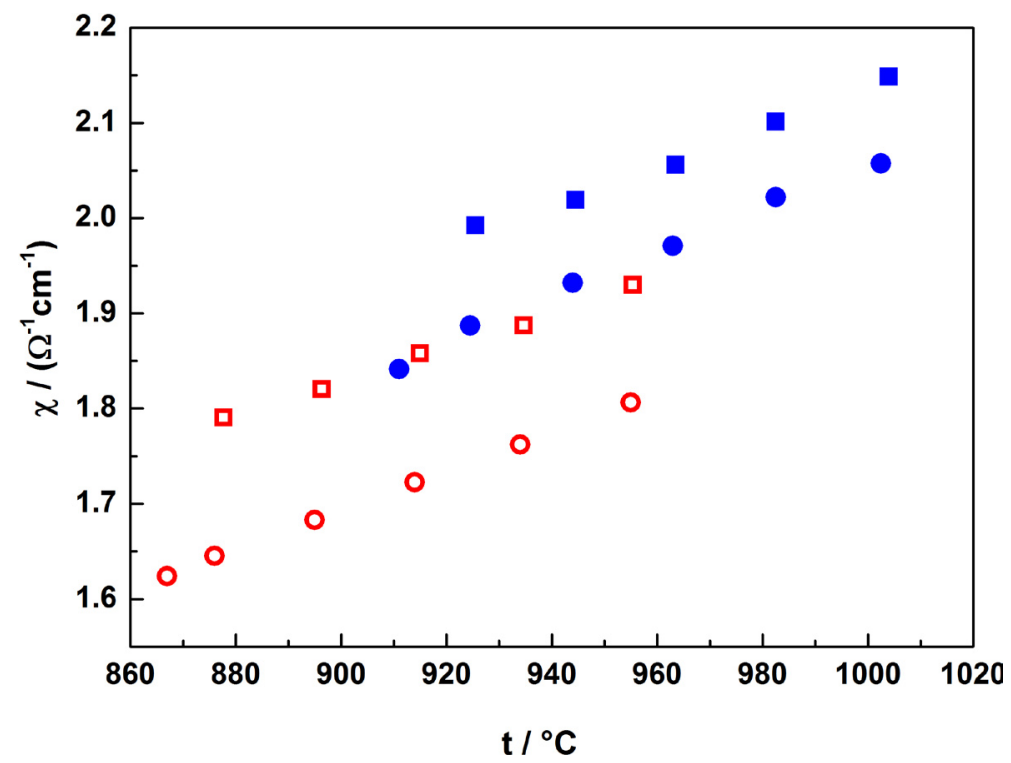

Fig. 5. Electrical conductivity of $\square \mathrm{NaF}-\mathrm{AlF}_{3}(\mathrm{MR}=1.8), \square \mathrm{NaF}^{-\mathrm{AlF}_{3}}(\mathrm{MR}=1.6)$,

- $\mathrm{NaF}-\mathrm{AlF}_{3}-\mathrm{Al}_{2} \mathrm{O}_{3}-\mathrm{CaF}_{2}(\mathrm{MR}=1.8), \circ \mathrm{NaF}-\mathrm{AlF}_{3}-\mathrm{Al}_{2} \mathrm{O}_{3}-\mathrm{CaF}_{2}(\mathrm{MR}=1.6)$ systems as a function of temperature.

the temperature range of $865{ }^{\circ} \mathrm{C}$ to $1005{ }^{\circ} \mathrm{C}$ were determined. An increased content of aluminium fluoride was found to lead to the considerable reduction of the operating temperature, up to $100^{\circ} \mathrm{C}$ lower than in industrial baths. Unfortunately, this compound and also the addition of other components into the electrolyte cause the reduction of electrical conductivity. More significant influence was noticed for the addition of alumina, while the effect of calcium fluoride was insignificant. Electri- cal conductivity increased only with ascending bath temperature in our measurements. One of the possibilities of partial suppression of the electrical conductivity decline is the addition of lithium fluoride.

\section{Acknowledgement}

This work was supported by the Ministry of Education, Science, Research and Sport of the Slovak Republic within the projects VEGA 1/0543/15 and VEGA 1/0101/14. 


\section{References}

Bakin KB, Simakova ON, Polyakov PV, Mikhalev YG, Simakov DA, Gusev AO (2010) Russian Metallurgy 2010: 707-711.

Cassayre L, Palau P, Chamelot P, Massot L (2010) J. Chem. Eng. Data 55: 4549-4560.

Galasiu I, Galasiu R, Thonstad J (2007) Inert Anodes for Aluminium Electrolysis, Düsseldorf.

Híveš J, Thonstad J, Sterten A, Fellner P (1993) Electrochim. Acta 38: 2165-2169.

Híveš J, Thonstad J, Sterten Å, Fellner P (1996) Metall. Mater. Trans. B 27: 255-261.

Híveš J, Thonstad J (2004) Electrochim. Acta 49: $5111-5114$.

Kan H, Wang Z, Ban Y, Shi Z, Qui Z (2007) T. Nonferr. Metal. Soc 17: 181-186.
Kvande H, Drabløs PA (2014) J. Occup. Environ. Med 56: 23-32.

Redkin A, Tkacheva O (2010) J. Chem. Eng. Data 55: 1930-1939.

Solheim A, Sterten Å (1997) In: Thonstad J (Ed) Ninth International Symposium on Light Metals Production (pp 225-234). Thondheim.

Thonstad J, Fellner P, Haarberg GM, Híveš J, Kvande H, Sterten $\AA$ (2001) Aluminium Electrolysis, Fundamentals of the Hall-Héroul Process. Düsseldorf.

Uher D, Čirka L, Kamenár J, Híveš J (2009) Acta Chimica Slovaca 2: 25-30.

Wang X, Peterson RD, Tabereaux AT (1993) Light Metals: 247-255. 